\title{
Establishment of a Pathogenicity Index for Mice to Pasteurella multocida Strains Isolated from Poultry and Swine
}

\section{-Author(s)}

\section{Emery BD' \\ Furian TQ' \\ Chitolina GZ \\ Pilatti RM' \\ Borges KA' \\ Salle CTP' \\ Moraes HLS'}

Departamento de Medicina Animal, Centro de Diagnóstico e Pesquisa em Patologia Aviária (CDPA), Faculdade de Veterinária (FAVET), Universidade Federal do Rio Grande do Sul (UFRGS), Porto Alegre, RS, Brazil.

\section{-Mail Address}

Corresponding author e-mail address Brunna Dias de Emery

Av. Bento Gonçalves, 8824 - Zip code: 91540-000, Porto Alegre, RS, Brazil.

Tel: $\quad$ (51) 83584046

Email: brunnademery@hotmail.com

\section{EKeywords}

Mice, Pasteurella multocida, pathogenicity index.

\section{ABSTRACT}

Fowl cholera is a contagious disease that results from infection by the bacterium Pasteurella multocida. This microorganism is extensively distributed among animal species, but little is known regarding it's pathogenesis and specificity to various hosts. Many studies using pathogenicity evaluation methods are subjective and difficult to quantify because they are often only involved in the observation of the lethal capacity of the agent in experimental inoculation. Due to a lack of more consistent data, this study aimed to establish a classification model of $P$. multocida pathogenicity in mice using strains isolated from poultry and swine. A total of 94 strains of $P$. multocida isolated from clinical cases of FC and from lungs of swine were tested. A volume of $0.1 \mathrm{~mL}$ of bacterial suspension was obtained from the concentration of $10^{6} \mathrm{CFU} / \mathrm{mL}$ and inoculated by an intraperitoneal route in five mice. The animals were observed every six hours over seven days. In addition to the mortality observed, the time of death and gross lesions were also analyzed. The Pathogenicity Indexes obtained showed significant differences $(p<0.05)$ according to the origin of the strains. Likewise, the number of gross lesions and isolation percentages were also varied $(p<0.05)$ among strains isolated from poultry and swine. From the observed ratios, the isolates were grouped into three pathogenicity classes: high, medium and low. This study proposed a consistent measurement and classification of $P$. multocida pathogenicity. The obtained results will be used to generate other adjusted models, as well as to form the basis for disease diagnosis.

\section{INTRODUCTION}

The avian pasteurellosis or fowl cholera (FC) is a highly infectious systemic disease, the agent of which is the bacteria Pasteurella multocida. This disease usually results in high morbidity and mortality, and it is one of the most important in poultry farming because of worldwide economic losses (Wilkie et al., 2012). Other diseases resulting from infection by the same agent include progressive atrophic rhinitis in swine, hemorrhagic septicemia in cattle and buffaloes and pasteurellosis in rabbits (Alwis, 1992; Avante, 2008; Winn, 2008).

P. multocida is a commensal inhabitant of the respiratory and digestive tract of mammals and birds (Christensen \& Bisgaard, 2006). However, this bacterium can become pathogenic if the host is exposed to factors that compromise its immune system, such as stress, environmental changes or other infections. Thus, the pathogenicity of $P$. multocida is variable and depends primarily on the virulence of the strain and the host species involved (Nascimento et al., 2009).

Despite the number of diseases that $P$. multocida causes and the economic impact associated with these diseases, little is known regarding 
Emery BD, Furian TQ, Chitolina GZ, Pilatti RM, Borges KA, Salle CTP Moraes HLS
Establishment of a Pathogenicity Index for Mice to Pasteurella multocida Strains Isolated from Poultry and Swine the pathogenesis and virulence of various strains (Wilkie et al., 2012). Several pathogenicity assessment methodologies involve only the agent's lethal capacity (Rajini, 1995; Wilkie, 2000), providing subjective data regarding the true pathogenic capacity of bacteria. In addition, animal models, such as mice, are generally used to confirm the diagnosis of FC (Dziva et al., 2008). Due to the lack of more consistent data, the objective of this study was to establish a classification model of the pathogenicity of $P$. multocida, isolated from clinical cases of FC and from swine through the inoculation of mice.

\section{MATERIALS AND METHODS}

\section{Strains of Pasteurella multocida}

A total of 94 strains of $P$. multocida isolated from clinical cases of $F C$ and from swine lungs taken at slaughter, in southern Brazil were selected. All samples were stored in sheep blood medium at a temperature of $-80^{\circ} \mathrm{C}$. Reactivation of the strains to confirm the purity of the samples was performed according to Glisson et al. (2008) and Furian et al. (2013). The isolates were reactivated in brain heart infusion broth $\left(\mathrm{BHI}^{-O x o i d^{\circledR}}\right)^{\circledR}$ and incubated at $37^{\circ} \mathrm{C}$ for 24 hours. Next, the samples were plated into two different culture media: blood agar $\left(\mathrm{Oxoid}^{\circledR}\right)$ containing $5 \%$ defibrinated sheep blood and MacConkey agar $\left(\mathrm{Oxoid}^{\circledR}\right)$, which inhibits the growth of $P$. multocida. The samples were incubated again at $37^{\circ} \mathrm{C}$ for 24 hours. After this period, the colonies present on the blood agar plates were evaluated according to their morphology. Finally, the catalase and oxidase tests were performed, and a species-specific PCR for detection of the gene kmt1 was performed according to the protocol developed by Townsend et al. (1998).

\section{Preparation of the inoculum}

The inoculum preparation was performed according to the methodology described by Pilatti et al. (2016). The solution contained $10^{6} \mathrm{CFU} / \mathrm{mL}$ was defined as the standard inoculum, which corresponds to the value of $\mathrm{LD}_{50}$ determined by Pilatti et al. (2016) and Hazarika et al. (2011). For the preparation of the inoculum, one colony of each sample from the overnight culture on blood agar supplemented with 5\% debrinated sheep blood was transferred to a tube containing 5 $\mathrm{mL}$ of sterile $\mathrm{BHI}$ broth. After homogenization, $1 \mathrm{~mL}$ of this solution $\left(10^{7}\right)$ was transferred to another tube containing $9 \mathrm{~mL}$ of sterile $0.85 \%$ saline solution. Subsequently, $0.1 \mathrm{~mL}$ of this solution $\left(10^{6}\right)$ was used for the inoculation.

\section{Inoculation}

This project was approved by the Ethics Commission on Animal Use (CEUA) of the Veterinary Research Institute Desiderio Finamor (IPVDF), located in Eldorado do Sul, State of Rio Grande do Sul, conforming to protocol number 01/2015. A total of 470 Swiss heterogeneous 8-week-old mice were housed in temperature-controlled isolation rooms $\left(22 \pm 2^{\circ} \mathrm{C}\right)$. The animals were placed inside experimental plastic containment boxes, and they received water and feed in the form of pellet ad libitum. For each strain evaluated, five mice were inoculated with $0.1 \mathrm{~mL}$ of the inoculum through the intraperitoneal route. The control group composed of 5 mice was inoculated with $0.1 \mathrm{~mL}$ of $0.85 \%$ sterile saline solution through the same route.

\section{Mortality and evaluation of the presence of macroscopic lesions}

Mortality of the challenged mice was evaluated at intervals of six hours over seven days. The dead animals were necropsied, and the presence of five macroscopic lesions for mice (conjunctivitis, inflammatory lesion at the site of application, congested/hemorrhagic liver and congested/hemorrhagic lungs, pericarditis) were evaluated (Figure 1)

\section{Isolation of Pasteurella multocida}

Fragments of heart and spleen were collected aseptically and inoculated in $5 \mathrm{~mL}$ of $\mathrm{BHI}$ broth $\left(\mathrm{Oxoid}^{\circledR}\right.$ ) to obtain bacterial isolates. The diagnosis followed the same steps previously described for the reactivation of P. multocida strains (Glisson et al., 2008; Furian et al., 2013)

\section{Calculation of individual pathogenicity index (IPI)}

The IPI was based on the study described by Souza et al. (2016) and Pilatti et al. (2016) with several modifications. The IPI corresponds to the pathogenicity index (PI) for each animal in each group inoculated with a strain of $P$. multocida and was calculated on a scale between 0 and 10. A value of 10 was established as the maximum pathogenicity rate for an inoculated mouse. For it's determination, the time of death (TD) and the presence of the five macroscopic lesions (Figure 1) were considered. The two parameters received equal weight, corresponding to 5 points each. Due to the absence of mortality in the first 6 hours, mice that died after 12 hours post-inoculation received a maximum value of 1 for the TD. From 18 hours and later, the TD 

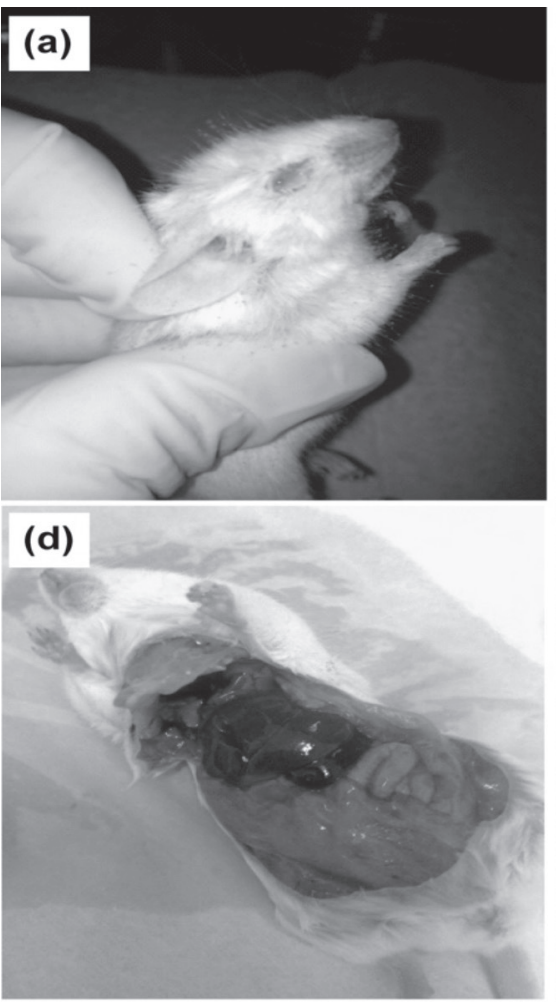

(b)
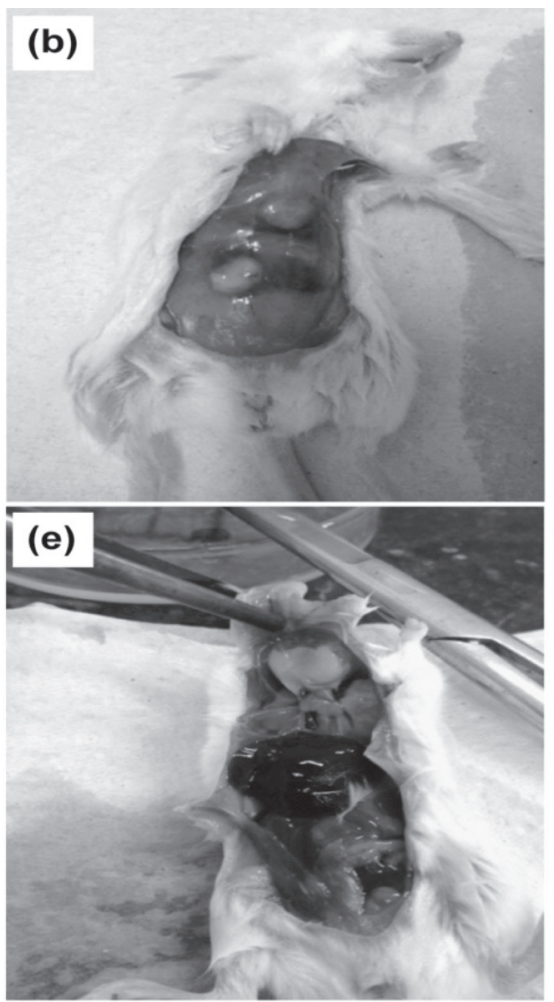

(c)

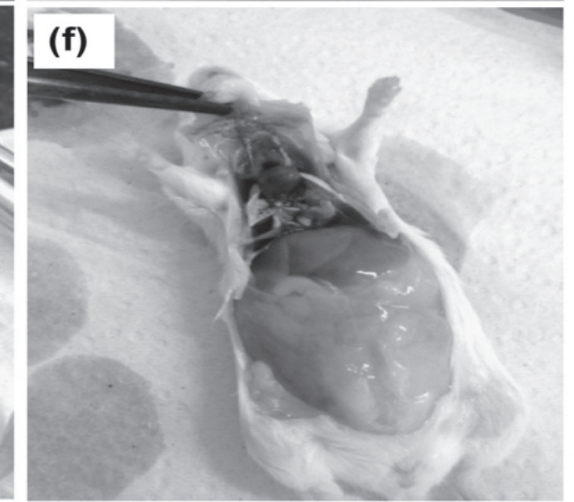

Figure 1 - Macroscopic lesions observed in the necropsied mice after inoculation with the selected strains of Pasteurella multocida. (a) conjunctivitis; (b) inflammatory lesion at the site of application; (c) congested liver; (d) hemorrhagic lung; (e) pericarditis; ( $f$ ) animal without lesion.

was divided by the number of times that the animals were evaluated over seven days, resulting in a value of 0.0357 , which corresponded to a survival bonus factor. Thus, for every 6 hours that the mice survived, 0.0357 of the maximum factor 1 was discounted. The values obtained for the TD were multiplied by 5, corresponding to the maximum score of points for this parameter. The five remaining points correspond to the sum of the five macroscopic lesions evaluated. The mice that died in the first 12 hours received the maximum scores for the two evaluated criteria, resulting in a maximum IPI value of 10 . The remaining animals did not receive a score for TM at the end of the seven days of observation; only the respective sum of the five macroscopic lesions was counted for the IPI.
Thus, the IPI was generated according to the following equation:

$* I P I=T D \times 5+(C O N J+I L+L C+H C+P C)$

*IPI: Individual Pathogenicity Index; TD: Time of Death; CONJ: Conjunctivitis; IL: Inflammatory lesion at the site of application; LC: lung congestion; HC: Hepatic congestion; PC: Pericarditis.

The PI for each inoculated strain was calculated according to the equation below:

$$
\frac{* \mathrm{PI}=\Sigma(\mathrm{IPI})}{\mathrm{N}}
$$

*PI: Pathogenicity index of the strain; $\Sigma($ IPI): Sum of IPI; N: Number of inoculated mice in the same group.

Table 1 - Example of the establishment of the Pathogenicity Index (PI) of Pasteurella multocida strains inoculated in five Swiss heterogeneous 8-week-old mice.

\begin{tabular}{|c|c|c|c|c|c|c|c|c|c|c|c|}
\hline Strain & Animal & $\mathrm{Hrs}$ & TD & FBS & CONJ & $\mathrm{IL}$ & $\mathrm{LC}$ & $\mathrm{HC}$ & $P C$ & Lesion & $\mathrm{IPI}$ \\
\hline \multirow{5}{*}{824} & 1 & 30 & 0.8929 & 4.46 & 0 & 0 & 1 & 1 & 0 & 2 & 6.46 \\
\hline & 2 & 36 & 0.8572 & 4.29 & 0 & 0 & 1 & 1 & 0 & 2 & 6.29 \\
\hline & 3 & 54 & 0.7501 & 3.75 & 0 & 0 & 1 & 1 & 0 & 2 & 5.75 \\
\hline & 4 & 72 & 0.643 & 3.22 & 0 & 1 & 1 & 1 & 1 & 4 & 7.22 \\
\hline & 5 & 78 & 0.6073 & 3.04 & 0 & 1 & 1 & 1 & 1 & 4 & 7.04 \\
\hline
\end{tabular}

PI: 6.55

Hrs: Survival time in hours; TD: Time of death; FBS: Survival bonus factor (FBS); CONJ: Conjunctivitis; IL: Inflammatory lesion; LC: Lung congestion; HC: Hepatic congestion; PC: Pericarditis. 1: Presence of lesion; 0: Absence of lesion; IPI: Individual Pathogenicity Index; PI: Pathogenicity index of the strain. 
Emery BD, Furian TQ, Chitolina GZ, Pilatti RM, Borges KA, Salle CTP Moraes HLS
Establishment of a Pathogenicity Index for Mice to Pasteurella multocida Strains Isolated from Poultry and Swine

\section{Statistical analysis}

The Kruskal-Wallis, Mann-Whitney and Dunn's nonparametric statistical tests were selected to verify the significance of the statistical variation among strain origins, time of death, percentage of macroscopic lesions and PI. The statistical program Graphpad Prism version 6.0 was used with a significance level of $5 \%$.

\section{RESULTS AND DISCUSSION}

\section{Mortality and time of death}

The mortality percentage of mice inoculated with avian and swine strains according to the total period evaluated is described in Graphic 1. There was a significant difference $(p<0.05)$ in the time of death among the strains isolated from the two origins. The mortality percentage was significantly higher $(p<0.05)$ among avian strains, especially in the first 48 hours and between 78 and 96 hours post-inoculation.

Graphic 1 - Relative frequency (\%) of mortality and time of death (hours) of Swiss heterogeneous 8-week-old mice observed during seven days after inoculation with avian and swine Pasteurella multocida strains.

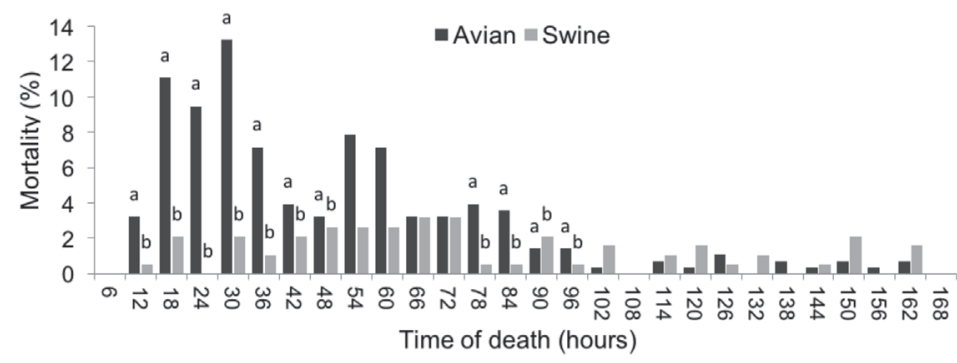

* Different letters in the same column represent significant difference between the groups $(p<0.05)$, Mann-Whitney test.

The inoculation by strains of avian origin usually causes death of the mice within 24 to 48 hours (Rimler \& Glisson 1997). The highest mortality among poultry strains was up to 48 hours after inoculation (51.46\%), which is in agreement with the literature (Ozbey, Muz 2006). According to observations performed at intervals of 6 hours, it was possible to identify mortality peaks of the mice inoculated with the avian strains at 18, 24, 30 and 36 hours after inoculation (Graphic 1). Despite the low and constant mortality of the mice inoculated with the swine strains, a peak between 48 and 72 hours (14.19\%) after inoculation was observed (Graphic 1). This mortality period was also observed by Hazarika et al. (2011) for most animals inoculated with swine strains.

\section{Evaluation of the presence of macroscopic lesions and bacterial isolation}

Clinical signs such as ruffled fur, dyspnea, apathy, anorexia and cyanosis at the extremities, especially close to the time of death were observed after 12 hours post-inoculation. Several animals also presented purulent ocular discharge and, rarely, torticollis and locomotive discomfort, which were associated with the lymphadenopathy evidenced at the necropsy. The study on the evaluation of pathogenicity of $P$. multocida type B in mice conducted by Ahmed et al. (2014) revealed similar clinical signs.

At necropsy, the mice presented with evident macroscopic lesions, which differed in intensity and extent among $P$. multocida strains, as occurred with time of death (TD).

Graphic 2 shows the percentage of bacterial isolation and the frequency of the five macroscopic lesions evaluated in the study. According to the percentage of the lesion frequency, it was observed that the strains of avian origin caused a higher number of lesions in the inoculated mice. The occurrence of hepatic and lung congestion were significantly higher $(p<0.05)$ among avian strains. The same finding was observed in relation to the percentage of bacterial isolation (Graphic 2).

Graphic 2 - Relative frequency (\%) of macroscopic lesions and bacterial isolation according to the origin of Pasteurella multocida strains.

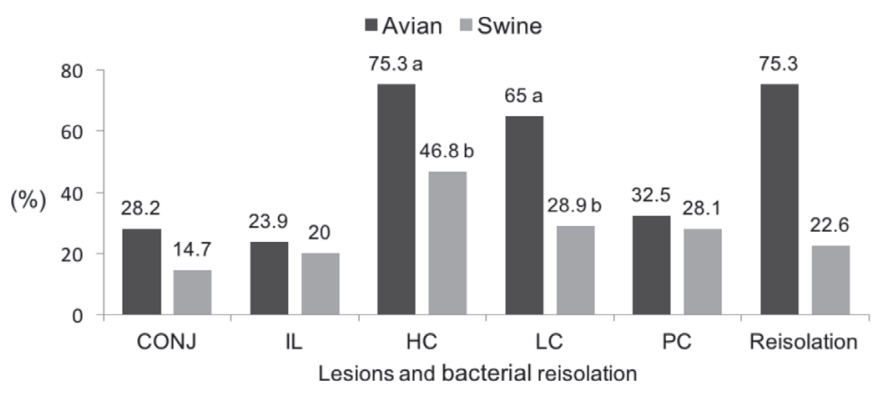

CONJ: Conjunctivitis; IL: Inflammatory lesion at the site of application; HC: hepatic congestion; LC: lung congestion; PC: Pericarditis. Different letters in the same column represent significant difference between the groups $(p<0.05)$.

Among the animals that presented macroscopic lesions, hepatomegaly with congestion and petechiae, as well as the presence of white or yellowish spots in the liver, were frequently observed. Akhtar (2013) observed similar septicemic lesions with necrosis and hemorrhage in the liver and heart when mice were inoculated with $P$. multocida strains of avian origin. The lung, an organ for which $P$. multocida presents a higher tropism (Nascimento et al., 2009), has generally demonstrated 
Emery BD, Furian TQ, Chitolina GZ, Pilatti RM, Borges KA, Salle CTP Moraes HLS

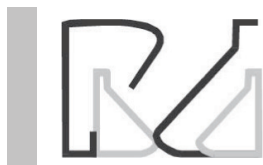

moderate to severe congestion in addition to the occurrence of petechiae. The heart was another organ that also presented alteration. A thick fibrinous layer formed on the pericardium in most of the cases.

At the site of inoculum application, an inflammatory process that was characterized by a yellowish lesion in the peritoneum was observed. This lesion was also described by Pilatti (2016) in one day-old chicks inoculated with the same strains selected for this study. Eventually, the spleen also presented macroscopic lesions. In spleens, congestion and splenomegaly were observed, however, the lesions were not considered in the calculation of PI because the identification of these lesions was difficult. Another finding that was less frequent (1\%) was lymphadenopathy, specifically in the subiliac lymph nodes. Animals with enlarged lymph nodes showed slight discomfort in the posterior limbs when they moved. Randani et al. (1990) observed the death of all mice inoculated with strains of $P$. multocida type $B$ isolated from ruminants within a short period of time, as well as lesions similar to hemorrhagic septicemia in cattle, such as lymphadenopathy, splenomegaly and petechial hemorrhage between 12 and 24 hours postinfection. The presence of lymphadenopathy in mice suggests a relationship between this type of lesion and the pathogenic capacity of the strain. In addition, Ahmed et al. (2014) highlights that when inoculation is performed by the intraperitoneal route, the primary sites for colonization are the peritoneum and lymphatic system of the region. Subsequently, the microorganism disseminates through the body and migrates to the tissue most suitable for its multiplication (Ahmed et al., 2014). According to the period of observation in this study, it was possible to verify the time required for the formation of some lesions. Conjunctivitis, hepatic and lung congestion were generally observed within the first 12 hours after inoculation of the mice. Conversely, the inflammatory lesion at the site of application and pericarditis were observed only at 18 hours and 42 hours after inoculation.
Establishment of a Pathogenicity Index for Mice to Pasteurella multocida Strains Isolated from Poultry and Swine

The frequency of bacterial isolation was higher among the avian strains, which were also more pathogenic. Other studies also showed higher success in recovering samples from organs of animals that died within 24 to 48 hours after inoculation with avian $P$. multocida strains (Balakrishan; Roy, 2012). According to Ozbey and Muz (2006), it is possible that nonreisolated strains are not lethal to mice because when the virulence is lower, the difficulty of detecting the strains in this animal model is increased. The data in Table 2 verified that the isolation was higher in the first and second days of death. This finding probably explains the fact that the majority of swine strains presented low mortality, less macroscopic lesions, and lower frequency of bacterial isolation.

Table 2 - Frequency (\%) of bacterial isolation and daily mortality of Swiss heterogeneous 8-week-old mice inoculated with Pasteurella multocida strains.

\begin{tabular}{lcccc}
\hline \multirow{2}{*}{ Day } & \multicolumn{2}{c}{ Mortality (\%) } & \multicolumn{2}{c}{ Isolation (\%) } \\
\cline { 2 - 5 } & Avian & Swine & Avian & Swine \\
\hline 1 & 23.57 & 2.63 & 89.39 & 100 \\
\hline 2 & 27.85 & 7.89 & 85.89 & 60 \\
\hline 3 & 20.71 & 11.57 & 72.41 & 45.45 \\
\hline 4 & 10.71 & 3.68 & 70 & 71.42 \\
\hline 5 & 1.42 & 4.21 & 75 & 62.5 \\
6 & 2.14 & 2.1 & 50 & 25 \\
7 & 1.78 & 3.68 & 60 & 42.85 \\
\hline $7 *$ & 11.42 & 64.21 & 40.62 & 4.09 \\
\hline${ }^{*}$ Mice that survived and were euthanized after 168 hours of observation.
\end{tabular}

\section{Pathogenicity index}

Based on mortality parameters and the presence of macroscopic lesions, a PI was calculated for the avian and swine strains on a scale of 0 to 10 . The 94 strains of $P$. multocida were classified into three pathogenicity groups according to the PI and shown in Table 3.

The majority of avian strains presented intermediate to high pathogenicity, unlike the swine strains that showed predominantly intermediate and low Pls. The median Pls of the groups with intermediate and low

Table 3 - Median values of Pathogenicity Index (PI) obtained according to the distribution of avian and swine strains of $P$. multocida inoculated in the pathogenicity groups.

\begin{tabular}{|c|c|c|c|}
\hline Origin & Pathogenicity group & $\mathrm{N}^{\circ}$ of strains & Median \pm Standard deviation \\
\hline \multirow{4}{*}{ Avian } & High (PI from 7.1 to 10 ) & 16 & $9.46 \pm 1.061^{a}$ \\
\hline & Intermediate (PI from 3.1 to 7 ) & 36 & $6.27 \pm 0.903^{b}$ \\
\hline & Low (PI from 0 to 3 ) & 4 & $2.4 \pm 1.575^{b}$ \\
\hline & High (PI from 7.1 to 10 ) & 3 & $7.83 \pm 1.324^{a}$ \\
\hline \multirow{2}{*}{ Swine } & Intermediate (PI from 3.1 to 7 ) & 11 & $5.74 \pm 0.917^{a}$ \\
\hline & Low (PI from 0 to 3 ) & 24 & $0 \pm 0.903^{b}$ \\
\hline
\end{tabular}

Different letters in the same column represent significant difference between the groups $(p<0.05)$, Kruskal-Wallis test. 
Emery BD, Furian TQ, Chitolina GZ, Pilatti RM, Borges KA, Salle CTP Moraes HLS
Establishment of a Pathogenicity Index for Mice to Pasteurella multocida Strains Isolated from Poultry and Swine pathogenicity did not present significant difference ( $p>0.05$ ); however, these two groups differed from the high pathogenicity PI median. Regarding the 38 strains of swine origin, there were no significant differences ( $p>0.05)$ between the high and intermediate pathogenicity groups, but both were significantly different $(p<0.05)$ from the low pathogenicity group.

The results of this work were similar to those described by Pilatti (2016) regarding the higher pathogenicity of avian strains compared to the isolates from swine. Several virulence factors are considered fundamental only for a specific host species. For this reason, certain strains are genetically capable of inducing disease in one host and do not cause disease in others (Ewers et al., 2006). The high pathogenicity observed in part of the avian isolates, as well as for some swine isolates, confirms the pathogenic potential of strains of these origins in mice.

P. multocida is the main causative agent of FC (Quinn, 2005), but the microorganism is usually present in mixed infections in swine, and for this reason, its action as a primary pathogen or as an opportunistic invader is still unclear (Borowski et al., 2007). Several studies have demonstrated an increase in the pathogenic potential of $P$. multocida strains when associated with other agents (Ciprian et al., 1988; Hansen, 2010; Morés, 2015). Conversely, Oliveira Filho and collaborators (2015) refer to this microorganism as the primary cause of pneumonia in pigs, highlighting the importance of the genetic variability of the circulating strains among the herds and their influence on the pathogenic capacity for the animals. It is possible that as in the pigs, an increase in the pathogenic potential occurs in mice when $P$. multocida acts together with other microorganisms. However, the evidence of several high Pls for swine strains demonstrates the ability of some strains of $P$. multocida to induce disease in mice, even when evaluated as the sole etiological agent.

A similar model of pathogenicity classification was described by Pilatti et al. (2016) through the experimental inoculation in one day-old chicks with the strains selected for this study. The authors also observed a significant difference $(p<0.05)$ between the Pls of the groups in which the strains were distributed. However, unlike Pilatti et al. (2016), the interval of 6 hours for the observation of the mice and for mortality evaluation was adopted in the current study, thereby generating more precise results.

The pathogenicity classification model proposed in this study may be used in future studies aimed at characterizing the virulence of $P$. multocida strains. In
2016, Furian et al., proposed a method of conditional interference through the use of classification trees for 22 genes associated with virulence. Those authors used the Pls established by Pilatti (2016) in the correlation of marker genes of pathogenicity. From that work, the authors identified virulence genes associated with pathogenicity levels in avian strains of $P$. multocida. In addition, the Pls obtained can be used in the construction of artificial neural networks to classify the pathogenicity of strains without the need of inoculation of animals, as was reported by Souza (2010) using strains of $E$. coli from avian origin.

\section{CONCLUSIONS}

The PI that was described, selecting the time of death and the presence of five macroscopic lesions, enabled the classification of the P. multocida strains in different groups. This methodology can be used in the future to assess the pathogenicity of the isolates, especially in the case of bacteria that may be involved in respiratory syndromes.

\section{REFERENCES}

Ahmed WA, AL Gebouri NM, Al Maaly NM. Study the pathogenicity of Pasteurella multocida in mice. Basrah Journal of Veterinary Research 2014; $1(1): 312-323$

Aktar M. Isolation, identification and characterization of Pasteurella multocida from chicken and development of oil based vaccine [dissertation]. Mymensingh (BD): Bangladesh Agricultural University; 2013.

Alwis MCL. Haemorrhagic septicaemia: a general review. British Veterinary Journal 1992;148(2):99-112.

Avante ML, Zangirolami Filho D, Ferreira MMG, Rosa BRT, Martins IS, Lot RFE. Rinite atrófica dos suínos. Revista Cientifica Eletrônica de Medicina Veterinária 2008;6(10):1-7.

Balakrishan G, Roy P. Isolation, identification and antibiograma of Pasteurella multocida isolates of avian origin. Journal of Veterinary \& Animal Sciences 2012;8(4):199-202.

Borowski SM, Barcellos D, Morés N. Pasteurelose pulmonar. In: Sobestiansky J, Barcellos D, editors. Doenças dos suínos. Goiânia: Cânone Editorial; 2007. p.177-181

Christensen H, Bisgaard M. The genus Pasteurella. In: Dworkin M, editor. The prokaryotes. $3^{\text {rd }}$ ed. New York: Springer; 2006. p.1062-1090.

Ciprián A, Pijoan C, Cruz T, Camacho J, Tórtora J, Colmenares G, et al Mycoplasma hyopneumoniae increases the susceptibility of pigs to experimental Pasteurella multocida pneumonia. Canadian Journal of Veterinary Research 1988;52(4):434-438.

Dziva F, Muhairwa AP, Bisgaard M, Christensen H. Diagnostic and typing options for investigating diseases associated with Pasteurella multocida. Veterinary Microbiology 2008;128(1-2):1-22.

Ewers C, Lübke-Becker A, Bethe A, Kiebling S, Filter M, Wieler LH. Virulence genotype of Pasteurella multocida strains isolated from different hosts 
with various disease status. Veterinary Microbiology 2006;114(34):304-317.

Furian TQ, Borges KA, Pilatti RM, De Almeida CN, Streck AF, De Emery BD, et al. Use of molecular pathogenicity indices to identify pathogenic strains of Pasteurella multocida. Avian Diseases 2016;60(4):792-798.

Furian TQ, Borges KA, Rocha SLS, Rodrigues EE, Nascimento VP, Salle CTP, et al. Detection of virulence-associated genes of Pasteurella multocida isolated from cases of fowl cholera by multiplex-PCR. Pesquisa Veterinária Brasileira 2013;33(2):177-182.

Glisson JR. Pasteurellosis and others respiratory bacterial infection. In: Saif YM, editor. Diseases of poultry. $12^{\text {th }}$ ed. Ames: Blackwell Publishing; 2008. p.739-758.

Hansen MS, Pors SE, Jensen HE, Bille-Hansen V, Bisgaard M, Flachs EM, et al. An investigation of the pathology and pathogens associated with porcine respiratory disease complex in denmark. Journal of Comparative Pathology 2010;143(2-3):120-131.

Hazarika MP, Barman NN, George S, Sharma RK. Characterization of Pasteurella multocida isolated from pneumonic pigs of Assam. Indian Journal of Animal Research 2011;44(4):265-269.

Morés MAZ, Oliveira Filho JX, Rebelatto R, Klein CS, Barcellos DEN, Coldebella $A$, et al. Aspectos patológicos e microbiológicos das doenças respiratórias em suínos de terminação no Brasil. Pesquisa Veterinária Brasileira 2015:35(8):725-733.

Nascimento VP, Gama NMSQ, Canal CW. Coriza infecciosa das galinhas, pasteureloses e outras infecções bacterianas relacionadas. In: Berchieri JA, Silva EN, Fábio JD, Sesti L, Zuanaze MAF, editors. Doenças das aves. 2nd ed. Campinas: FACTA; 2009. p.503-530.

Oliveira Filho JX, Morés MAZ, Rebelatto $R$, Agnol AMD, Plieski CLA, Klein CS, et al. Pasteurella multocida type $A$ as the primary agent of pneumonia and septicaemia in pigs. Pesquisa Veterinária Brasileira 2015;35(8):716-724.

Ozbey G, Muz A. Isolation of aerobic bacteria from the lungs of chickens showing respiratory disorders and confirmation of Pasteurella multocida by polymerase chain reaction (PCR). Veterinary Archives 2006;76(3):217-225.

Pilatti RM, Furian TQ, Lima DA, Finkler F, Brito BG, Salle CTP, et al. Establishment of a pathogenicity index for one-day-old broilers to
Pasteurella multocida strains isolated from clinical cases in poultry and swine. Brazilian Journal of Poultry Science 2016;18(2):1-6.

Quinn PJ, Markey BK, Carter ME, Donnelly WJC, Leonard FC. Gênero pasteurella e a Mannheimia haemolytica. In: Quinn PJ, Markey BK, Carter ME, Donnelly WJC, Leonard FC. Microbiologia veterinária e doenças infeciosas. Porto Alegre: Artmed; 2005. p.143-148.

Rajini R, Rao A, Seshagiri, Dhanalakshmi K, Sarma BJR. Studies on avian pasteurellosis in Andhra Pradesh. Indian Veterinary Journal

1995:72:115-118

Randani, Dawkins HJS, Johnson RB, Spencer TL, Adler B. Pasteurella multocida infections in mice with reference to haemorragic septicemia in cattle and buffalo. Immunology \& Cell Biology 1990;68(1):57-61.

Rimler RB, Glisson JR. Fowl cholera. In: Calnek BW, Barnes HJ, Beard CW, McDougald LR, Saif YM. Diseases of poultry. $10^{\text {th }}$ ed. Ames: lowa State University Press; 1997. p.143-161.

Souza GF, Rocha SLS, Furian TQ, Borges KA, Salle FO, Moraes LB, et al. Classification of avian pathogenic Escherichia coli by a novel pathogenicity index based on an animal model. Acta Scientiae Veterinariae 2016;44:1347

Souza GF. Estabelecimento de um novo índice de patogenicidade para amostras de E. coli e o uso de redes neurais artificiais [thesis]. Porto Alegre (RS): Universidade Federal do Rio Grande do Sul; 2010.

Townsend KM, Frost AJ, Lee CW, Papadimitriou JM, Dawkins HJ. Development of PCR assays for species - and type-specific identification of Pasteurella multocida isolates. Journal of Clinical Microbiology 1998;16(4):1096-1100

Wilkie IW, Grimes SE, O'Boyle D, Frost AJ. The virulence and protective efficacy for chickens of pasteurella multocida administered by different routes. Veterinary Microbiology 2000;72(1-2):57-68.

Wilkie IW, Harper M, Boyce JD, Adler B. Pasteurella multocida: diseases and pathogenesis. Current Topics in Microbiology and Immunology $2012 ; 361: 1-22$

Winn WC, Allen SD, Janda WM, Koneman EW, Procop GW, Schreckenberger PC, et al. Koneman, diagnóstico microbiológico. 6th ed. Rio de Janeiro: Guanabara Koogan; 2008. p. 453-459. 
